\title{
Chemical and genetic diversity of high-seed-yield sorghum (Sorghum bicolor M.) germplasms
}

\author{
J. Ryu' ${ }^{1}$, S.B. Im ${ }^{1}$, S.J. Kwon ${ }^{1,2}$, J.W. Ahn ${ }^{1,2}$, S.W. Jeong ${ }^{1}$ and S.Y. Kang ${ }^{1}$ \\ ${ }^{1}$ Advanced Radiation Technology Institute, \\ Korea Atomic Energy Research Institute, Jeongup, Korea \\ ${ }^{2}$ Unversity of Science and Technology, \\ Radiation Biotechnology and Applied Radioisotope Science, Daejeon, Korea \\ Corresponding author: S.Y. Kang \\ E-mail: sykang@kaeri.re.kr
}

Genet. Mol. Res. 15 (3): gmr.15038677

Received March 30, 2016

Accepted May 10, 2016

Published September 2, 2016

DOI http://dx.doi.org/10.4238/gmr.15038677

Copyright (C) 2016 The Authors. This is an open-access article distributed under the terms of the Creative Commons Attribution ShareAlike (CC BY-SA) 4.0 License

\begin{abstract}
This study evaluated the chemical and genetic diversity of high-seed-yield sorghum germplasms from Korea, the United States, and South Africa. We identified significant differences in the chemical contents of whole plants at the heading stage in all cultivars, including differences in crude protein, fat, fiber, ash, neutral detergent fiber, acid detergent fiber, mineral, and fatty acid contents. Our results suggest that Banwoldang is the most appropriate cultivar for roughage because of its high protein yield. We identified significant differences in the tannin, flavonoid, amylose, mineral, crude fat, fatty acid, and 3-deoxyanthocyanin contents in the whole grain from all cultivars, but not in the mineral or crude fat contents. Tannin levels were generally low. IS645 contained the highest levels of flavonoids and linolenic acid compounds, and Moktak had the highest amylose and deoxyanthocyanidin content in the grain. To assess genetic diversity, we used 10 simple sequence repeat (SSR) primer sets to identify 38
\end{abstract}


alleles with 3-8 alleles per locus. Based on phylogenetic analysis of the SSR markers, the sorghum cultivars were divided into three major groups. Comparison of clusters based on chemical compositions with those based on SSRs showed that the groups formed by the three native Korean cultivars clustered similarly in molecular dendrograms. Association analysis was conducted for the 10 SSR marker; 48 chemical and growth traits were present for two marker traits (seed color and whole plant fatty acid content) with significant marker-trait associations. These markers could be used to select sorghum cultivars for breeding programs.

Key words: Chemical analysis; SSR marker; Marker-trait associations; Sorghum

\section{INTRODUCTION}

Sorghum is the fifth most important cereal crop in the world after wheat, rice, corn, and barley (FAO, 2004). Sorghum is used for food, animal feed, fibers in wallboards, fences, biodegradable packing material, and for ethanol production (Rooney and Waniska, 2000; Awika and Rooney, 2004; Mehmood et al., 2008; Iqbal et al., 2010). The grain is used mostly for food in the form of flat breads and porridges (thick or thin) in Asia and Africa, and as animal feed in the Americas (http://www.icrisat.org/crop-sorghum.htm). The use of sorghum for food has increased recently because of its gluten-free characteristic and other potential health benefits, which include its slow digestibility and cholesterol-lowering, anti-carcinogenic, and antiinflammatory properties (Dykes et al., 2009). These qualities increase the economic benefits for farmers, and enable breeders to select genotypes with both good grain yield and sugary stalks to provide a dual-purpose crop. The whole sorghum plant has also been increasingly used as an important source of fodder for livestock. In recent years, sorghum forage quality has improved through extensive breeding efforts and through the selection of highly nutritious cultivars. The quality of forage sorghum cultivars can be equal to or higher than that of corn (Mohammad et al., 2014).

An important aspect of crops is their diverse pool of fatty acids (Rooney and Waniska, 2000). Although fatty acid intake affects the quality of meat produced, studies on the fatty acid composition of various forage crops have been limited. The crude fat content of sorghum grains is higher than that of wheat and rice, but lower than that of maize. Since cereal crops with low oil content do not serve as significant domestic oil sources, their importance is limited to the atypical advantages of their fatty acid constituents (Rooney and Waniska, 2000; Mehmood et al., 2008).

Sorghums vary widely in their phenolic composition and content, with both genetics and the environment affecting the kinds and levels of phenolic compounds present (Awika et al., 2004). Flavonoids in sorghums include phenolic compounds, of which, tannins and anthocyanins are the most important flavonoids isolated from sorghum (Rooney and Waniska, 2000; Awika et al., 2004). Tannin content in the pericarp is one of the most important factors affecting the feed value of sorghum grain, since it adversely affects the metabolizable energy in grain and protein utilization by poultry (Sedghi et al., 2011). The most common anthocyanins

Genetics and Molecular Research 15 (3): gmr.15038677 
in sorghum are the 3-deoxyanthocyanidins, which include luteolinidin and apigeninidin (Awika et al., 2004). Sorghum has a wide variety of phenolics and their composition is affected by genotype (Dykes et al., 2009).

Simple sequence repeats (SSRs or microsatellites) are one of the most commonly used DNA molecular markers to determine genetic diversity between sorghum genotypes (Motlhaodi et al., 2014; Lu et al., 2015). Knowledge on genetic diversity and the phytochemical relationships among accessions in crop germplasm collections is essential for establishing, managing, and ensuring the long-term success of crop improvement programs (Gebhardt et al., 2004).

This study aimed to demonstrate that selected sorghum germplasms with high yield and high-sugar content characteristics might have the potential to be sources of significant nutritive value, minerals, fatty acids, tannins, flavonoids, and anthocyanins. We used SSR markers to evaluate genetic diversity and demonstrate significant associations between the SSR markers and composition.

\section{MATERIAL AND METHODS}

\section{Plant materials}

We used 10 sorghum cultivars obtained from the Rural Development Association GenBank in 2013 (Table 1). These lines were cultivated from 2013 to 2015 at the breeding farm of the Advanced Radiation Technology Institute at the Korean Atomic Energy Research Institute (Republic of Korea) and were selected to verify whether seed production was possible (Table S1). To select the superior sources, we evaluated three major growth characteristics of the sorghum cultivars, including dry yield, seed yield, and sugar content. The seeds were planted in plots $(3 \times 15 \mathrm{~m})$ and row spacing of 20 and $60 \mathrm{~cm}$, respectively. Sorghum was collected from a 3 x 3-m quadrant and three biological replicates were used for each sample. Grain color was divided into two types: black and red. The heading dates for the selected sorghum cultivars ranged from July 24 to August 12, 2014.

\begin{tabular}{|c|c|c|c|c|}
\hline No. & Cultivar name & Origin & Grain pigment & Heading date \\
\hline 1 & DINE-A-M & Unknown & Black & Aug. 12 \\
\hline 2 & IS645 & United States & Black & Aug. 7 \\
\hline 3 & IS2868 & South Africa & Black & Aug. 4 \\
\hline 4 & Moktak & Korea (cultivar) & Black & Aug. 10 \\
\hline 5 & Banwoldang & Korea (cultivar) & Red & Jul. 28 \\
\hline 6 & ChalI & Korea (native species) & Black & Aug. 10 \\
\hline 7 & ChalII & Korea (native species) & Red & Jul. 30 \\
\hline 8 & KLSO79125 & Korea (native species) & Black & Aug. 6 \\
\hline 9 & KLSO79075 & Korea (native species) & Black & Jul. 24 \\
\hline 10 & Mesusu & Korea (native species) & Black & Aug. 10 \\
\hline
\end{tabular}

\section{Harvest and sugar content estimation}

Whole plants from 10 cultivars were harvested at the heading dates of each cultivar. Each cultivar was harvested after the grain reached the hard dough stage. Sugar content (brix) was determined using a hand-held refractometer (Atago PR-101 $\alpha$; Atago USA Inc.). Sugar content was estimated based on the method described by Wortmann et al. (2010), which 
assumes that $75 \%$ of the sugar content is fermentable sugars.

\section{Forage value analysis}

Dry matter $(\mathrm{DM})$ values of whole plants were determined by drying $100 \mathrm{~g}$ material at $60^{\circ} \mathrm{C}$ in a forced air oven for $90 \mathrm{~h}$ (AOAC, 1990). Dried samples were ground using a Wiley mill, passed through a 1-mm screen, and subjected to laboratory tests for forage nutritional value. DM was also calculated for ground samples by drying $1 \mathrm{~g}$ sample at $104^{\circ} \mathrm{C}$ in a forcedair oven for $6 \mathrm{~h}$ to determine moisture corrections for fiber fraction analyses. Samples were analyzed for neutral detergent fiber (NDF) and acid detergent fiber (ADF) contents using an ANKOM fiber analyzer (Ankom Technology Corp., Fairport, NY, USA), and analyzed for crude protein (CP) content using AOAC methods (AOAC, 1990).

\section{Mineral content}

We determined the mineral content of the sorghum cultivars using analytical methods as previously described (AOAC 1995). Both grain and whole plant samples (1.0 g) were weighed and subjected to dry ashing in a clean porcelain crucible at $550^{\circ} \mathrm{C}$ in a muffle furnace. The resultant ash was dissolved in $5.0 \mathrm{~mL} \mathrm{HNO}_{3} / \mathrm{HCl} / \mathrm{H}_{2} \mathrm{O}(1: 2: 3)$ and heated gently on a heating mantle until the brown fumes disappeared. We then added $5.0 \mathrm{~mL}$ distilled water to each sample in the crucible, where they were heated until a colorless solution was obtained. The mineral solution was filtered into a $100-\mathrm{mL}$ volumetric flask through filter paper. The solution was analyzed in triplicate to determine its elemental composition using a Perkin Elmer Model 403 atomic absorption spectrophotometer.

\section{Crude fat content and fatty acid analysis}

Grain oil content was analyzed using the AOAC method as previously described (AOAC, 1990). Using the Soxhlet extraction procedure, $5 \mathrm{~g}$ crushed seeds ( 80 mashed) were packed into a thimble and the oils were extracted with diethyl ether for $6 \mathrm{~h}$. The lipid extracts of the grain and the whole plant were mixed with boron trifluoride $\left(\mathrm{BF}_{3}\right)$-methanol reagent $(20 \%)$ and the fatty acids were converted into methyl ester derivatives. The methyl esters of the fatty acids were dissolved in chloroform $\left(\mathrm{CHCl}_{3}\right)$ and analyzed by gas chromatographymass spectrometry (Plus-2010, Shimadzu, Kyoto, Japan). The fatty acid composition of whole plants and grain was analyzed using a GC-MS instrument equipped with an HP-88 capillary column (J\&W Scientific $60 \mathrm{~m} \times 0.25 \mathrm{~mm} \times 0.25 \mathrm{~m}$ ) under the following conditions: ionization voltage, $70 \mathrm{eV}$; mass scan range, $35-450$ mass units; injector temperature, $230^{\circ} \mathrm{C}$; detector temperature, $230^{\circ} \mathrm{C}$; inject volume, $1 \mu \mathrm{L}$; split ratio, 1:30; carrier gas, helium; and flow rate, $1.7 \mathrm{~mL} / \mathrm{min}$. The column temperature program specified an isothermal temperature of $40^{\circ} \mathrm{C}$ for 5 min followed by an increase to $180^{\circ} \mathrm{C}$ at a rate of $5^{\circ} \mathrm{C} / \mathrm{min}$ and a subsequent increase to $28^{\circ} \mathrm{C}$ at a rate of $1{ }^{\circ} \mathrm{C} / \mathrm{min}$. We identified the substances present in extracts by comparing their mass spectra against a database of GC-MS (Nist. 62 Library) spectra and by their retention indices.

\section{Total tannin content}

Tannin content was determined using the Folin-Ciocalteu method (Makkar, 2000).

Genetics and Molecular Research 15 (3): gmr.15038677 
Tannin was extracted with methyl alcohol and Folin-Ciocalteu reagent was added to the mixture and incubated for $90 \mathrm{~min}$ at room temperature. The absorbance level was measured at $725 \mathrm{~nm}$ using a UV-spectrophotometer (UV-1800, Simazuda, Japan). Standard curves are expressed as catechin equivalents.

\section{Total flavonoids}

Total flavonoid content was measured using the aluminum chloride colorimetric method (Zhishen et al., 1999). An aliquot $(1 \mathrm{~mL})$ of each extract was added to a $10-\mathrm{mL}$ volumetric flask containing $4 \mathrm{~mL}$ double distilled water. We then added $0.3 \mathrm{~mL} 5 \% \mathrm{NaNO}_{2}$ to the flask and, after $5 \mathrm{~min}, 0.3 \mathrm{~mL} \mathrm{10 \%} \mathrm{AlCl}_{3}$ was also added. After $6 \mathrm{~min}, 2 \mathrm{~mL} \mathrm{NaOH}$ was added and the total volume was brought to $10 \mathrm{~mL}$ with double distilled water. The solution was mixed completely and the absorbance level was measured and compared to that of the prepared reagent blank at $510 \mathrm{~nm}$. The total flavonoid assay was measured three times for each extract. Standard curves were expressed as quercetin equivalents.

\section{Anthocyanin content}

The anthocyanin content was determined using the method described by Awika et al. (2004). The whole grain (with the bran) was extracted sequentially with $\mathrm{HCl}: \mathrm{MeOH}(1: 99)$. The extraction procedure involved the addition of $5 \mathrm{~mL}$ solvent to $0.2 \mathrm{~g}$ sample in a 15$\mathrm{mL}$ centrifuge tube, which was then shaken for $2 \mathrm{~h}$ at $20^{\circ} \mathrm{C}$ in the dark. Samples were then equilibrated to room temperature and centrifuged at $7000 \mathrm{~g}$ for $10 \mathrm{~min}$ and decanted. All extracts were immediately filtered using a 0.45 -mm membrane filter prior to ultra-performance liquid chromatography (UPLC) analysis. Anthocyanins were analyzed using a UPLC system (CBM20A, Shimadzu Co. Ltd., Japan) with two gradient pump systems (LC-30AD, Shimadzu), a UV-detector (SPD-M30A, Shimadzu), an auto sample injector, and a column oven. Separation was achieved on an HSS T3 column $(2.1 \times 100 \mathrm{~mm}, 1.8 \mathrm{~mm}$, waters Inc., USA) using a linear gradient elution program with a mobile phase containing solvent A and solvent B. The anthocyanins were separated using the following gradients: $0-5 \mathrm{~min}, 10-15 \% \mathrm{~B} ; 5-10$ min, $15-20 \%$ B; 10-15 min, 20-30\% B; 15-20 min, 30-50\% B; 20-25 min, 50-75\% B; 25-30 min, $75-100 \%$ B; 30-32 min, 100-5\% B; and 32-35 min, 5-0\% B; The 3-deoxyanthocyanins were detected at $480 \mathrm{~nm}$ and identified using commercial standards with the exception of the glycosides of apigeninidin, which were identified based on their UV spectra (Table S2 and $\underline{\text { Figure S1A }}, \underline{\mathbf{B}}, \underline{\mathbf{C}}$ ) and published data (Awika et al. 2004; Dykes et al., 2009).

\section{DNA extraction and SSR analysis}

DNA extractions were performed from young leaves of each selected cultivar using the cetyltrimethylammonium bromide method (Fang et al., 1992). Ten SSR primer sets were used for analyses of genetic diversity and marker-trait associations (Agrama and Tuinstra, 2003). PCR was carried out in $25-\mu \mathrm{L}$ mixtures containing 20 ng genomic DNA, 10 pmol primer, 1 unit Taq polymerase, 10X PCR buffer, and $0.2 \mathrm{mM}$ dNTP. The PCR cycling conditions were as follows: $94^{\circ} \mathrm{C}$ for $5 \mathrm{~min}$ (initial denaturation) followed by 40 cycles at $94^{\circ} \mathrm{C}$ for 45 $\mathrm{s}$ (predenaturation), $55^{\circ} \mathrm{C}$ for $45 \mathrm{~s}$ (annealing), $72^{\circ} \mathrm{C}$ for $90 \mathrm{~s}$ (extension), with a final 7 -min extension at $72^{\circ} \mathrm{C}$ and cooling to $4^{\circ} \mathrm{C}$. The samples were fractionated using a Lapchip GX 
electrophoresis system (Caliper Life Science, USA).

\section{Statistical analysis}

Data obtained from chemical analyses were subjected to analysis of variance using a multiple comparisons method with the statistical software package SPSS version 12 (SPSS Institute, USA). Differences were determined to be significant at $\mathrm{P}<0.05$. When the treatment effect was significant, means were separated using the Duncan multiple range tests. The resulting matrix of chemical similarity was calculated on the basis of the Pearson's correlation coefficient. The resulting matrix of chemical data was used to construct a dendrogram using the average linkage method with the statistical software package SPSS V.12.

All of the SSR bands were scored as 0 or 1 according to the absence or presence of bands, respectively. The number of alleles $\left(N_{\mathrm{A}}\right)$, the effective number of alleles $\left(N_{\mathrm{E}}\right)$, and gene diversity $(h)$ were estimated using the computer program POPGENE 1.32. The dendrogram was constructed using the unweighted pair-group method with arithmetic mean (UPGMA) algorithm and the NTSYSPC PC program.

We determined marker-trait associations using TASSEL 3.0.1 software (Bradbury et al., 2007). We performed three tests for significance. First, the Q general linear model (GLM) was performed on the chosen Q-matrix derived from STRUCTURE with 10,000 permutations to test marker significance and to determine the experiment-wise $P$ value for each marker's significance. Second, the Q-mixed linear model (Q-MLM) method was used to determine a kinship matrix. SPAGeDi (Hardy and Vekemans, 2002) was used to calculate kinship (K) coefficients.

\section{RESULTS}

\section{Growth characteristics and sugar content}

The growth characteristics and sugar content of the cultivars used in this study are shown in Table 2. We observed significant differences for most of the growth and yield characteristics including plant height and seed yield. The sugar content of all the cultivars ranged from 8.5 to 17.5 brix. The DINE-A-MITE cultivar had the highest sugar content. The highest seed yield was recorded for the IS2868 cultivar from South Africa.

Table 2. Growth characteristics and sugar content of Sorghum germplasm.

\begin{tabular}{l|c|c|c}
\hline Cultivar names & Plant height $(\mathrm{cm})$ & Seed yield $(\mathrm{kg} / \mathrm{ha})$ & Sugar content (brix)* \\
\hline DINE-A-MITE & $272.6 \pm 10.5^{\mathrm{c}}$ & $680.2 \pm 31.9^{\mathrm{f}}$ & $17.5 \pm 0.5^{\mathrm{a}}$ \\
\hline IS645 & $258.5 \pm 8.2^{\mathrm{d}}$ & $790.2 \pm 26.1^{\mathrm{d}}$ & $14.2 \pm 0.4^{\mathrm{b}}$ \\
\hline IS2868 & $258.1 \pm 7.1^{\mathrm{d}}$ & $1230.2 \pm 34.4^{\mathrm{a}}$ & $13.6 \pm 0.5^{\mathrm{c}}$ \\
\hline Moktak & $242.4 \pm 6.6^{\mathrm{e}}$ & $710.3 \pm 12.7^{\mathrm{e}}$ & $13.0 \pm 0.6^{\mathrm{c}}$ \\
\hline Banwoldang & $316.2 \pm 9.4^{\mathrm{a}}$ & $1140.4 \pm 29.6^{\mathrm{b}}$ & $8.50 \pm 0.2^{\mathrm{e}}$ \\
\hline ChalI & $241.9 \pm 4.1^{\mathrm{e}}$ & $660.0 \pm 23.7^{\mathrm{f}}$ & $13.1 \pm 0.4^{\mathrm{f}}$ \\
\hline ChalII & $318.1 \pm 8.6^{\mathrm{a}}$ & $610.8 \pm 11.4^{\mathrm{g}}$ & $15.7 \pm 0.6^{\mathrm{b}}$ \\
\hline KLSO79125 & $310.0 \pm 7.2^{\mathrm{a}}$ & $610.4 \pm 23.5^{\mathrm{g}}$ & $12.2 \pm 0.6^{\mathrm{d}}$ \\
\hline KLSO79075 & $260.4 \pm 10.6^{\mathrm{d}}$ & $770.0 \pm 23.6^{\mathrm{d}}$ & $12.7 \pm 0.4^{\mathrm{d}}$ \\
\hline Mesusu & $293.0 \pm 6.3^{\mathrm{b}}$ & $960.8 \pm 12.2^{\mathrm{c}}$ & \\
\hline
\end{tabular}

* Sugar content: sugar content was evaluated on September 20. Superscript letters indicate significant differences at the 5\% level (Duncan's multiple range tests). 


\section{DM yields and chemical composition of whole plants}

The DM yields and nutritive values of whole plants for each sorghum cultivar are shown in Table 3. Among the cultivars studied, the highest dry yields on the heading date were observed for the Banwoldang cultivar, and the lowest yields were found for the IS645 cultivar.

Significant differences in nutritive value were observed among all the cultivars on the heading date. The CP contents of all cultivars ranged from 7.55 to $11.17 \%$. The highest values for CP and crude fat content were observed for the Chal I cultivar. The crude fiber contents of all e cultivars ranged from 29.22 to $35.03 \%$ and the highest contents were observed for the Chal II and KLSO79125 cultivars. The crude ash values for all cultivars were less than 8 . The lowest NDF and ADF contents were observed in the IS645 cultivar.

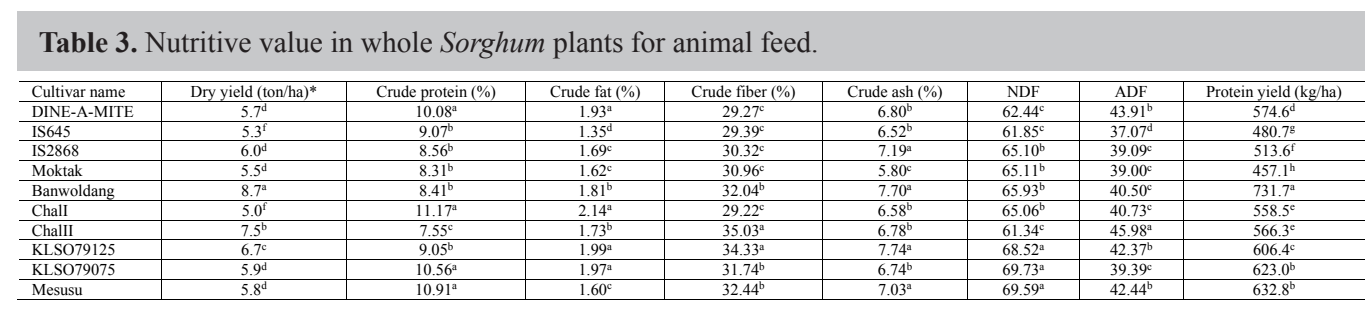

*Dry yield: whole plants were harvested at each heading date. Superscript letters indicate significant differences at the 5\% level (Duncan's multiple range tests).

The mineral contents of the selected sorghum cultivars are shown in Table 4 . Potassium, calcium, and phosphate were abundant minerals in whole plants. Among the various minerals, the highest concentrations were recorded for potassium in all cultivars. The highest calcium content in the whole plant was recorded for the KLSO79075 cultivar. The KLSO79125 cultivar had the highest phosphate and iron contents. And the highest potassium content was recorded for the Banwoldang cultivar.

Table 4. Mineral content in whole Sorghum plants.
\begin{tabular}{l|c|c|c|c|c|c|c}
\hline \multirow{2}{*}{ Cultivar name } & \multicolumn{7}{c}{ Mineral content $(\mathrm{mg} / 100 \mathrm{~g})$} \\
\cline { 2 - 8 } & $\mathrm{Ca}$ & $\mathrm{P}$ & $\mathrm{K}$ & $\mathrm{Mg}$ & $\mathrm{Na}$ & $\mathrm{Zn}$ & $\mathrm{Fe}$ \\
\hline DINE-A-MITE & $331.1^{\mathrm{c}}$ & $404.4^{\mathrm{c}}$ & $1706.5^{\mathrm{d}}$ & $381.2^{\mathrm{d}}$ & $13.0^{\mathrm{b}}$ & $3.3^{\mathrm{a}}$ & $7.3^{\mathrm{c}}$ \\
\hline IS645 & $294.0^{\mathrm{e}}$ & $317.3^{\mathrm{f}}$ & $1838.6^{\mathrm{c}}$ & $303.1^{\mathrm{f}}$ & $14.9^{\mathrm{a}}$ & $2.8^{\mathrm{a}}$ & $7.1^{\mathrm{c}}$ \\
\hline IS2868 & $303.8^{\mathrm{e}}$ & $318.4^{\mathrm{f}}$ & $1950.2^{\mathrm{b}}$ & $441.5^{\mathrm{c}}$ & $10.9^{\mathrm{d}}$ & $1.7^{\mathrm{b}}$ & $7.6^{\mathrm{c}}$ \\
\hline MOGTAK & $300.9^{\mathrm{e}}$ & $295.6^{\mathrm{g}}$ & $1563.0^{\mathrm{f}}$ & $310.8^{\mathrm{f}}$ & $11.9^{\mathrm{c}}$ & $2.1^{\mathrm{b}}$ & $5.7^{\mathrm{d}}$ \\
\hline BANWOLDANG & $341.3^{\mathrm{c}}$ & $376.1^{\mathrm{d}}$ & $2149.0^{\mathrm{a}}$ & $437.2^{\mathrm{c}}$ & $11.8^{\mathrm{c}}$ & $2.4^{\mathrm{b}}$ & $6.2^{\mathrm{d}}$ \\
\hline ChalI & $395.1^{\mathrm{b}}$ & $355.5^{\mathrm{e}}$ & $1662.7^{\mathrm{e}}$ & $474.6^{\mathrm{b}}$ & $12.9^{\mathrm{b}}$ & $3.2^{\mathrm{a}}$ & $7.2^{\mathrm{c}}$ \\
\hline ChalII & $312.3^{\mathrm{d}}$ & $251.0^{\mathrm{h}}$ & $1957.6^{\mathrm{b}}$ & $362.5^{\mathrm{d}}$ & $7.6^{\mathrm{f}}$ & $2.1^{\mathrm{b}}$ & $9.7^{\mathrm{b}}$ \\
\hline KLSO79125 & $421.5^{\mathrm{a}}$ & $464.2^{\mathrm{a}}$ & $1811.9^{\mathrm{c}}$ & $483.8^{\mathrm{b}}$ & $9.6^{\mathrm{e}}$ & $1.6^{\mathrm{b}}$ & $11.5^{\mathrm{a}}$ \\
\hline KLSO79075 & $435.7^{\mathrm{a}}$ & $355.2^{\mathrm{e}}$ & $1637.2^{\mathrm{e}}$ & $445.4^{\mathrm{c}}$ & $7.0^{\mathrm{f}}$ & $1.8^{\mathrm{b}}$ & $5.4^{\mathrm{e}}$ \\
\hline Mesusu & $397.7^{\mathrm{b}}$ & $422.0^{\mathrm{b}}$ & $1713.4^{\mathrm{d}}$ & $575.2^{\mathrm{a}}$ & $6.5^{\mathrm{g}}$ & $1.8^{\mathrm{b}}$ & $6.6^{\mathrm{d}}$ \\
\hline
\end{tabular}

Superscript letters indicate significant differences at the $5 \%$ level (Duncan's multiple range tests).

The fatty acid compositions of whole plants of the selected sorghum cultivars are shown in Table 5 and Figure S2. Palmitic (Figure S2A, peak 1) and linolenic acid (Figure $\underline{\text { S2A }}$, peak 6) were found to be the major fatty acids present in whole plants. The highest concentration of unsaturated fatty acids was recorded for the Mesusu cultivar, and the lowest concentration was recorded for the IS2868 cultivar (Figure S2A-J). 
Table 5. Fatty acid composition in whole Sorghum plants.

\begin{tabular}{|c|c|c|c|c|c|c|c|c|}
\hline Cultivar name & C16:0 & C16:1 & C18:0 & C18:1 & $\mathrm{C} 18: 2$ & $\mathrm{C} 18: 3$ & SF* & $\mathrm{UFA}^{* * *}$ \\
\hline DINE-A-MITE & $23.2^{\mathrm{b}}$ & $2.9^{\mathrm{b}}$ & $1.9^{\mathrm{b}}$ & $2.1^{\mathrm{d}}$ & $16.4^{\mathrm{c}}$ & $53.5^{\mathrm{c}}$ & $25.1^{\mathrm{c}}$ & $74.9^{\mathrm{c}}$ \\
\hline IS645 & $25.7^{\mathrm{b}}$ & $3.0^{\mathrm{b}}$ & $1.4^{\mathrm{d}}$ & $3.2^{\mathrm{a}}$ & $17.6^{\mathrm{b}}$ & $49.1^{\mathrm{e}}$ & $27.1^{\mathrm{b}}$ & $72.9^{\mathrm{d}}$ \\
\hline IS2868 & $27.8^{\mathrm{a}}$ & $2.2^{\mathrm{c}}$ & $1.9^{\mathrm{b}}$ & $2.2^{\mathrm{c}}$ & $20.7^{\mathrm{a}}$ & $45.2^{\mathrm{f}}$ & $29.7^{\mathrm{a}}$ & $70.3^{\mathrm{e}}$ \\
\hline MOGTAK & $23.9^{\mathrm{b}}$ & $3.5^{\mathrm{a}}$ & $1.5^{\mathrm{c}}$ & $3.0^{\mathrm{a}}$ & $16.4^{\mathrm{c}}$ & $51.7^{\mathrm{d}}$ & $25.4^{\mathrm{c}}$ & $74.6^{\mathrm{c}}$ \\
\hline BANWOLDANG & $23.2^{\mathrm{b}}$ & $3.1^{\mathrm{b}}$ & $1.6^{\mathrm{c}}$ & $2.4^{\mathrm{b}}$ & $15.3^{\mathrm{d}}$ & $54.5^{\mathrm{b}}$ & $24.8^{\mathrm{c}}$ & $75.3^{\mathrm{c}}$ \\
\hline ChalI & $22.5^{\mathrm{c}}$ & $3.8^{\mathrm{a}}$ & $2.0^{\mathrm{b}}$ & $1.9^{\mathrm{d}}$ & $14.6^{\mathrm{e}}$ & $55.2^{\mathrm{b}}$ & $24.5^{\mathrm{c}}$ & $75.5^{\mathrm{c}}$ \\
\hline ChalII & $22.7^{\mathrm{b}}$ & $2.9^{\mathrm{b}}$ & $2.4^{\mathrm{a}}$ & $2.6^{\mathrm{b}}$ & $15.4^{\mathrm{d}}$ & $54.0^{\mathrm{c}}$ & $25.1^{\mathrm{c}}$ & $74.9^{\mathrm{c}}$ \\
\hline KLSO79125 & $21.5^{\mathrm{c}}$ & $3.0^{\mathrm{b}}$ & $2.3^{\mathrm{a}}$ & $2.6^{\mathrm{b}}$ & $15.1^{\mathrm{d}}$ & $55.5^{\mathrm{b}}$ & $23.8^{d}$ & $76.2^{\mathrm{b}}$ \\
\hline KLSO79075 & $21.1^{\mathrm{c}}$ & $3.5^{\mathrm{a}}$ & $1.7^{\mathrm{c}}$ & $2.7^{\mathrm{b}}$ & $16.6^{\mathrm{c}}$ & $54.3^{\mathrm{b}}$ & $22.8^{\mathrm{e}}$ & $77.1^{\mathrm{a}}$ \\
\hline Mesusu & $20.8^{d}$ & $3.4^{\mathrm{a}}$ & $1.9^{\mathrm{b}}$ & $2.2^{\mathrm{c}}$ & $14.6^{\mathrm{e}}$ & $57.1^{\mathrm{a}}$ & $22.7^{\mathrm{e}}$ & $77.3^{\mathrm{a}}$ \\
\hline
\end{tabular}

$\mathrm{C} 16: 0=$ palmitic acid, C16:1 = palmitoleic acid, C18:0 = stearic acid, C18:1 = oleic acid, C18:2 = linoleic acid, $\mathrm{C} 18: 3=\alpha$-linolenic acid. Superscript letters indicate significant differences at the 5\% level (Duncan's multiple range tests). ${ }^{*} \mathrm{SF}=$ saturated fatty acid, $* * \mathrm{UFA}=$ unsaturated fatty acid.

\section{Chemical components of whole grain}

Amylose and mineral contents of the grain from sorghum cultivars are shown in Table 6. The Moktak cultivar had the highest amylose content, and the Chal I cultivar had the lowest amylose content. Phosphate, potassium, and magnesium were abundant in the grains of the sorghum cultivars. The mineral contents did not differ significantly among the cultivars.

Table 6. Amylose and mineral content in whole grain of Sorghum.

\begin{tabular}{l|c|c|c|c|c|c|c|c}
\hline \multirow{2}{*}{ Cultivar name } & Amylose content (\%) & \multicolumn{9}{c}{ Mineral content (m/g) } \\
\cline { 3 - 9 } & & $\mathrm{Ca}$ & $\mathrm{P}$ & $\mathrm{K}$ & $\mathrm{Mg}$ & $\mathrm{Na}$ & $\mathrm{Zn}$ & $\mathrm{Fe}$ \\
\hline DINE-A-MITE & $16.89^{\mathrm{b}}$ & $0.11^{\mathrm{a}}$ & $0.33^{\mathrm{a}}$ & $0.30^{\mathrm{a}}$ & $0.30^{\mathrm{a}}$ & $0.07^{\mathrm{a}}$ & $0.02^{\mathrm{a}}$ & $0.12^{\mathrm{a}}$ \\
\hline IS645 & $13.91^{\mathrm{c}}$ & $0.11^{\mathrm{a}}$ & $0.32^{\mathrm{a}}$ & $0.40^{\mathrm{a}}$ & $0.20^{\mathrm{a}}$ & $0.07^{\mathrm{a}}$ & $0.03^{\mathrm{a}}$ & $0.06^{\mathrm{a}}$ \\
\hline IS2868 & $14.17^{\mathrm{c}}$ & $0.12^{\mathrm{a}}$ & $0.24^{\mathrm{a}}$ & $0.20^{\mathrm{a}}$ & $0.30^{\mathrm{a}}$ & $0.07^{\mathrm{a}}$ & $0.03^{\mathrm{a}}$ & $0.07^{\mathrm{a}}$ \\
\hline MOGTAK & $21.35^{\mathrm{a}}$ & $0.12^{\mathrm{a}}$ & $0.30^{\mathrm{a}}$ & $0.44^{\mathrm{a}}$ & $0.30^{\mathrm{a}}$ & $0.06^{\mathrm{a}}$ & $0.02^{\mathrm{a}}$ & $0.04^{\mathrm{a}}$ \\
\hline BANWOLDANG & $11.46^{\mathrm{e}}$ & $0.11^{\mathrm{a}}$ & $0.31^{\mathrm{a}}$ & $0.50^{\mathrm{a}}$ & $0.30^{\mathrm{a}}$ & $0.07^{\mathrm{a}}$ & $0.03^{\mathrm{a}}$ & $0.05^{\mathrm{a}}$ \\
\hline ChalI & $10.76^{\mathrm{f}}$ & $0.12^{\mathrm{a}}$ & $0.32^{\mathrm{a}}$ & $0.32^{\mathrm{a}}$ & $0.22^{\mathrm{a}}$ & $0.10^{\mathrm{a}}$ & $0.03^{\mathrm{a}}$ & $0.05^{\mathrm{a}}$ \\
\hline ChalII & $12.16^{\mathrm{d}}$ & $0.12^{\mathrm{a}}$ & $0.41^{\mathrm{a}}$ & $0.51^{\mathrm{a}}$ & $0.30^{\mathrm{a}}$ & $0.07^{\mathrm{a}}$ & $0.02^{\mathrm{a}}$ & $0.04^{\mathrm{a}}$ \\
\hline KLSO79125 & $11.02^{\mathrm{e}}$ & $0.13^{\mathrm{a}}$ & $0.40^{\mathrm{a}}$ & $0.60^{\mathrm{a}}$ & $0.32^{\mathrm{a}}$ & $0.08^{\mathrm{a}}$ & $0.03^{\mathrm{a}}$ & $0.04^{\mathrm{a}}$ \\
\hline KLSO79075 & $11.64^{\mathrm{e}}$ & $0.11^{\mathrm{a}}$ & $0.40^{\mathrm{a}}$ & $0.50^{\mathrm{a}}$ & $0.30^{\mathrm{a}}$ & $0.07^{\mathrm{a}}$ & $0.02^{\mathrm{a}}$ & $0.04^{\mathrm{a}}$ \\
\hline Mesusu & $13.91^{\mathrm{c}}$ & $0.11^{\mathrm{a}}$ & $0.32^{\mathrm{a}}$ & $0.41^{\mathrm{a}}$ & $0.30^{\mathrm{a}}$ & $0.08^{\mathrm{a}}$ & $0.03^{\mathrm{a}}$ & $0.07^{\mathrm{a}}$ \\
\hline
\end{tabular}

Superscript letters indicate significant differences at the 5\% level (Duncan's multiple range tests).

The crude fat content and fatty acid composition of the grain from selected sorghum cultivars are shown in Table 7. No significant differences in crude fat content were observed among the cultivars. Palmitic, oleic, and linoleic acid were the principal fatty acids in the grain (Figure S3A-J). All of the cultivars had high linoleic acid level, with the IS2868 cultivar having the highest linoleic acid levels (Figure S3C), and the IS645 cultivar having the highest linolenic acid levels (Figure S3B $)$. The highest oleic acid levels were observed in the DINEA-MITE cultivar (Figure S3A).

The total tannin and flavonoid contents of the grains of the selected sorghum cultivars are shown in Figure 1. The total tannin content differed significantly among the cultivars (Figure 1A). The highest tannin content was recorded for the Banwoldang cultivar $(7.7 \mathrm{mg} / \mathrm{g})$, and the Chal I cultivar had the lowest content $(0.2 \mathrm{mg} / \mathrm{g})$.

Genetics and Molecular Research 15 (3): gmr.15038677 
Table 7. Crude fat content and fatty acid composition in whole grain of sorghum.

\begin{tabular}{l|c|c|c|c|c|c}
\hline & Crude fat (\%) & $16: 0$ & $18: 0$ & $18: 1$ & $18: 2$ & $18: 3$ \\
\hline DINE-A-MITE & $3.1^{\mathrm{a}}$ & $18.63^{\mathrm{d}}$ & $1.16^{\mathrm{a}}$ & $31.68^{\mathrm{a}}$ & $44.62^{\mathrm{c}}$ & $3.90^{\mathrm{h}}$ \\
\hline IS645 & $3.0^{\mathrm{a}}$ & $29.89^{\mathrm{a}}$ & $1.54^{\mathrm{a}}$ & $14.01^{\mathrm{g}}$ & $43.39^{\mathrm{c}}$ & $11.17^{\mathrm{a}}$ \\
\hline IS2868 & $3.0^{\mathrm{a}}$ & $26.49^{\mathrm{b}}$ & $0.00^{\mathrm{c}}$ & $20.73^{\mathrm{e}}$ & $47.07^{\mathrm{a}}$ & $5.71^{\mathrm{g}}$ \\
\hline MOGTAK & $3.2^{\mathrm{a}}$ & $24.90^{\mathrm{c}}$ & $0.58^{\mathrm{b}}$ & $25.04^{\mathrm{b}}$ & $40.86^{\mathrm{e}}$ & $8.63^{\mathrm{b}}$ \\
\hline BANWOLDANG & $3.3^{\mathrm{a}}$ & $26.89^{\mathrm{b}}$ & $1.62^{\mathrm{a}}$ & $19.45^{\mathrm{f}}$ & $45.48^{\mathrm{b}}$ & $6.55^{\mathrm{c}}$ \\
\hline ChalI & $3.3^{\mathrm{a}}$ & $26.32^{\mathrm{b}}$ & $0.66^{\mathrm{b}}$ & $22.51^{\mathrm{c}}$ & $44.40^{\mathrm{c}}$ & $6.10^{\mathrm{f}}$ \\
\hline ChalII & $3.1^{\mathrm{a}}$ & $27.55^{\mathrm{b}}$ & $1.11^{\mathrm{c}}$ & $22.88^{\mathrm{c}}$ & $43.23^{\mathrm{d}}$ & $5.24^{\mathrm{g}}$ \\
\hline KLSO79125 & $3.2^{\mathrm{a}}$ & $27.08^{\mathrm{b}}$ & $1.37^{\mathrm{b}}$ & $17.46^{\mathrm{g}}$ & $45.43^{\mathrm{b}}$ & $8.66^{\mathrm{b}}$ \\
\hline KLSO79075 & $3.1^{\mathrm{a}}$ & $27.14^{\mathrm{b}}$ & $1.59^{\mathrm{a}}$ & $20.87^{\mathrm{e}}$ & $43.40^{\mathrm{d}}$ & $7.00^{\mathrm{d}}$ \\
\hline Mesusu & $3.0^{\mathrm{a}}$ & $23.59^{\mathrm{c}}$ & $1.06^{\mathrm{a}}$ & $22.13^{\mathrm{d}}$ & $46.23^{\mathrm{b}}$ & $7.49^{\mathrm{c}}$ \\
\hline
\end{tabular}

$\mathrm{C} 16: 0=$ palmitic acid, $\mathrm{C} 18: 0=$ stearic acid, $\mathrm{C} 18: 1=$ oleic acid, $\mathrm{C} 18: 2=$ linoleic acid, $\mathrm{C} 18: 3=\alpha$-linolenic acid. Superscript letters indicate significant differences at the $5 \%$ level (Duncan's multiple range tests).

A

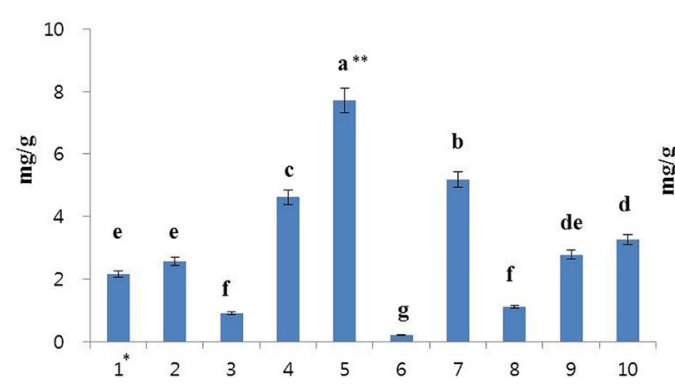

B

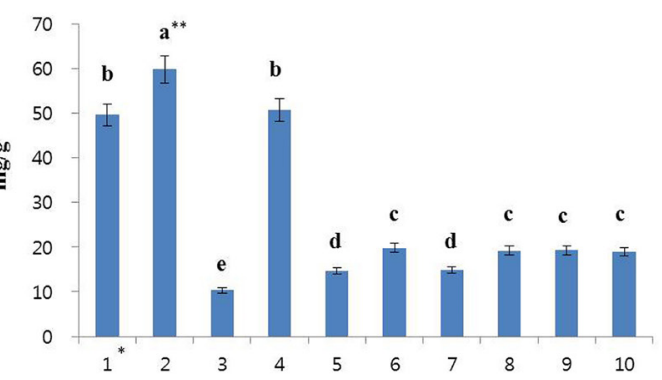

Figure 1. Tannin content and total flavonoid content in the germplasm of selected sorghum. *Germplasm number listed in Table 1. **Superscript letters indicate significant differences at the $5 \%$ level (Duncan's multiple range tests). A. Tannin content (mg/g), B. total flavonoid content $(\mathrm{mg} / \mathrm{g})$.

Total flavonoid content is shown in Figure 1B. The total flavonoid content for all cultivars ranged from 0.32 to $6.54 \mathrm{mg} / \mathrm{g}$. The IS645 cultivar contained higher levels of total flavonoid compounds than the other cultivars.

The anthocyanin contents of the grain are shown in Table 8. Three major 3-deoxyanthocyanins were detected: luteolinidin, apigeninidin, and glycosides of apigeninidin (Table S2). The red-colored sorghum (Figure 2D) cultivars had higher apigeninidin levels than the black-colored cultivars (Figure 2A, B, C). The Moktak cultivar had the highest amount of total 3-deoxyanthocyanidins in the grain $(8.96 \mathrm{mg} / 100 \mathrm{~g})$ followed by KLSO79075 (7.33 $\mathrm{mg} / 100 \mathrm{~g})>$ Chal I $(6.27 \mathrm{mg} / 100 \mathrm{~g}) \geq$ Mesusu $(5.52 \mathrm{mg} / 100 \mathrm{~g})>$ DINE-A-MITE $(5.31 \mathrm{mg} / 100$ g) $\geq$ Banwoldang $(5.28 \mathrm{mg} / 100 \mathrm{~g}) \geq \operatorname{KLSO} 79125(5.13 \mathrm{mg} / 100 \mathrm{~g})>\operatorname{IS} 645(3.50 \mathrm{mg} / 100 \mathrm{~g}) \geq$ Chal II $(2.94 \mathrm{mg} / 100 \mathrm{~g})>$ IS2868 $(1.86 \mathrm{mg} / 100 \mathrm{~g})$, in descending order (Table 8 and Figure S4A-J). The highest luteolinidin content $(6.59 \mathrm{mg} / 100 \mathrm{~g})$ was observed for the Moktak cultivar, and the lowest content was found for the Banwoldang cultivar $(0.04 \mathrm{mg} / 100 \mathrm{~g})$.

Values for Pearson's correlation coefficients (based on average quantified values for chemical data and growth characteristics) are shown in Table S3. The DM yield was positively correlated with crude fiber, crude ash, protein yield, potassium (for the whole plant), luteolinidin, apigeninidin, and seed color. The phosphate content of the whole grain (WG) was negatively correlated with seed yield. Seed color was correlated with luteolinidin and glycosides of apigeninidin. The crude fat of the whole plant (WP) was positively correlated with calcium content. The crude fiber content of whole pant was positively or negatively 
Table 8. 3-deoxyanthocyanin levels in the whole grain of Sorghum.

\begin{tabular}{l|c|c|c|c}
\hline Cultivar number & Luteolinidin $(\mathrm{mg} / 100 \mathrm{~g})$ & Apigeninidin $(\mathrm{mg} / 100 \mathrm{~g})$ & Glycosides of apigeninidin* $(\mathrm{mg} / 100 \mathrm{~g})$ & Total \\
\hline 1 & $2.63 \pm 0.42^{\mathrm{d}}$ & $2.46 \pm 0.32^{\mathrm{b}}$ & $0.22 \pm 0.04^{\mathrm{b}}$ & $5.31 \pm 0.77^{\mathrm{d}}$ \\
\hline 2 & $2.31 \pm 0.34^{\mathrm{d}}$ & $1.06 \pm 0.02^{\mathrm{c}}$ & $0.13 \pm 0.02^{\mathrm{d}}$ & $3.50 \pm 0.34^{\mathrm{e}}$ \\
\hline 3 & $1.17 \pm 0.16^{\mathrm{e}}$ & $0.57 \pm 0.04^{\mathrm{d}}$ & $0.06 \pm 0.01^{\mathrm{e}}$ & $1.81 \pm 0.13^{\mathrm{f}}$ \\
\hline 4 & $6.59 \pm 0.57^{\mathrm{a}}$ & $2.11 \pm 0.15^{\mathrm{b}}$ & $0.26 \pm 0.03^{\mathrm{b}}$ & $8.96 \pm 0.46^{\mathrm{a}}$ \\
\hline 5 & $0.04 \pm 0.00^{\mathrm{f}}$ & $4.19 \pm 0.59^{\mathrm{a}}$ & $1.05 \pm 0.16^{\mathrm{a}}$ & $5.28 \pm 0.76^{\mathrm{d}}$ \\
\hline 6 & $4.62 \pm 0.66^{\mathrm{b}}$ & $1.52 \pm 0.04^{\mathrm{c}}$ & $0.13 \pm 0.03^{\mathrm{d}}$ & $6.27 \pm 0.65^{\mathrm{c}}$ \\
\hline 7 & $1.27 \pm 0.13^{\mathrm{e}}$ & $1.50 \pm 0.03^{\mathrm{c}}$ & $0.17 \pm 0.02^{\mathrm{c}}$ & $2.94 \pm 0.17^{\mathrm{e}}$ \\
\hline 8 & $3.81 \pm 0.50^{\mathrm{c}}$ & $1.18 \pm 0.11^{\mathrm{c}}$ & $0.14 \pm 0.02^{\mathrm{d}}$ & $5.13 \pm 0.41^{\mathrm{d}}$ \\
\hline 9 & $4.65 \pm 0.56^{\mathrm{b}}$ & $2.39 \pm 0.25^{\mathrm{b}}$ & $0.29 \pm 0.02^{\mathrm{b}}$ & $7.33 \pm 0.34^{\mathrm{b}}$ \\
\hline Mean & $4.13 \pm 0.49^{\mathrm{b}}$ & $1.20 \pm 0.14^{\mathrm{c}}$ & $0.19 \pm 0.03^{\mathrm{c}}$ & $5.52 \pm 0.38^{\mathrm{c}}$ \\
\hline
\end{tabular}

*Tentatively identified as glycosides of apigeninidin (Awika et al., 2004; Dykes et al., 2009). Significant difference at the $5 \%$ determined by the Duncan test, values in each column represent the mean \pm standard deviation $(\mathrm{N}=3)$.

A

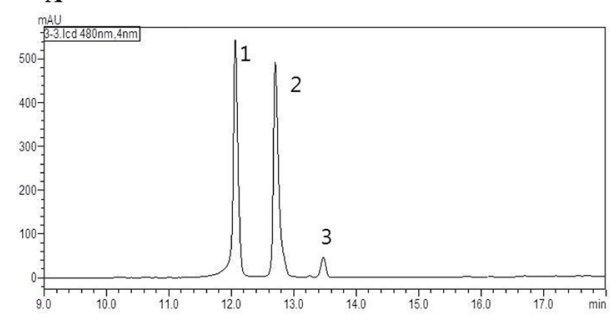

C

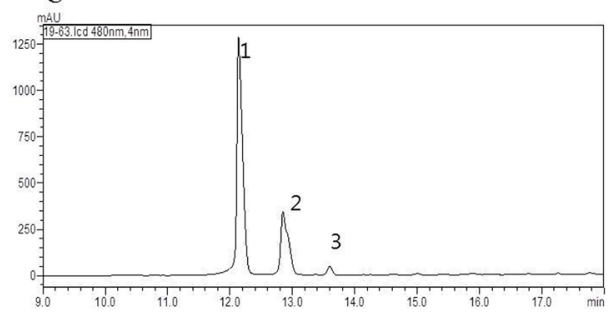

$\mathbf{B}$

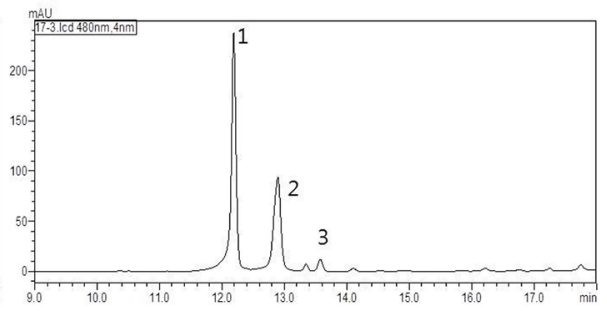

D

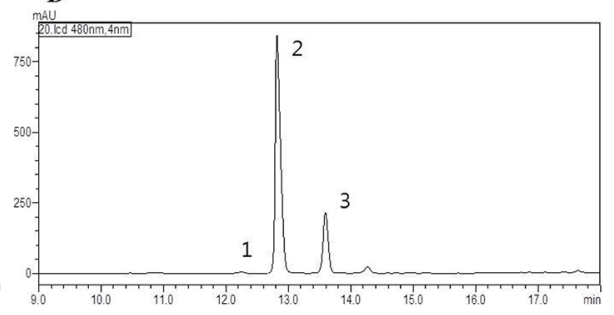

Figure 2. High performance liquid chromatography (HPLC) profiles of black and red sorghum 3-deoxyanthocyanins detected at $480 \mathrm{~nm}$. Peaks 1 and 2 are luteolinidin and apigeninidin, respectively. Peaks 3 was tentatively identified as glycosides of apigeninidin. Peaks were identified on the basis of matching retention times and spectral characteristics with commercial standards. A. DINE-A-MITE, B. IS2868, C. Moktak, D. Banwoldang.

correlated with sodium (WP), zinc (WP), phosphate (WP), and potassium (WG). The crude ash content of WP was positively or negatively correlated with potassium (WP), amylose (WG), linoleic acid (WG, and luteolinidin (WG). The NDF content was positively correlated with calcium (WP) and magnesium (WP). The ADF content was positively correlated with stearic acid (WP) and linolenic acid (WG). The calcium content of WP was positively or negatively correlated with phosphate (WP), magnesium (WP), palmitic acid (WP), and linolenic acid (WG). The phosphate content of WP was positively correlated with magnesium (WP). The potassium content of whole plant was negatively correlated with total 3-deoxyanthocyanins (WG). The magnesium content of whole plant was positively or negatively correlated with 
oleic acid (WP) and linoleic acid (WG). The sodium content of whole plant was positively correlated with zinc (WP). The iron content was positively correlated with stearic acid (WP). The palmitoleic acid of whole plant was positively correlated with total 3-deoxyanthocyanins (WG). The phosphate of whole grain was positively correlated with potassium (WG) and stearic acid (WP).

\section{Analysis of genetic diversity}

We evaluated genetic diversity and genetic relationships using SSR markers (Table 9). In total, 38 loci were found with 10 primer sets in 10 cultivars. $N_{\mathrm{A}}$ for each primer set was 3-8 with a mean value of 3.8 per set. $N_{\mathrm{E}}$ of each primer combination ranged from 1.00-1.77 with an average of 1.39. The maximum values for $h$ were found with the primer combination SbAGE01 (0.43), while the SbAGA01 primer combination did not detect genetic diversity.

\begin{tabular}{|c|c|c|c|c|c|}
\hline Primer name & Sequence $\left(5^{\prime}-3^{\prime}\right)$ & Number of alleles & $N_{\mathrm{A}}$ & $N_{\mathrm{E}}^{*}$ & $h^{* *}$ \\
\hline \multirow[t]{2}{*}{ SbAGA01 } & F: CGAACCATGATAAATGACTG & \multirow[t]{2}{*}{3} & \multirow[t]{2}{*}{1.00} & \multirow[t]{2}{*}{1.00} & \multirow[t]{2}{*}{0.00} \\
\hline & R: ATCCGTTTCACAAAAAAAGT & & & & \\
\hline \multirow[t]{2}{*}{ SbAGE01 } & F: GACCGATCTAATGATGCA G & \multirow[t]{2}{*}{3} & \multirow[t]{2}{*}{2.00} & \multirow[t]{2}{*}{1.77} & \multirow[t]{2}{*}{0.43} \\
\hline & R: ACGGTAGAGAAGACCCATC & & & & \\
\hline \multirow[t]{2}{*}{ SbAGB02 } & F: CTCTGATATGTCGTTGTG CT & \multirow[t]{2}{*}{3} & \multirow[t]{2}{*}{1.33} & \multirow[t]{2}{*}{1.07} & \multirow[t]{2}{*}{0.06} \\
\hline & R: ATAGAGAGGATAGCTTATAGCTCA & & & & \\
\hline \multirow[t]{2}{*}{ SbAGG02 } & F: ATCCATGCATATCCGAC & \multirow[t]{2}{*}{3} & \multirow[t]{2}{*}{1.67} & \multirow[t]{2}{*}{1.38} & \multirow[t]{2}{*}{0.22} \\
\hline & R: TTCGTCACCCACAACATAC & & & & \\
\hline \multirow[t]{2}{*}{ SbAGB03 } & F: GTGTGTGTAGCTTCTTGGG & \multirow[t]{2}{*}{3} & \multirow[t]{2}{*}{1.67} & \multirow[t]{2}{*}{1.67} & \multirow[t]{2}{*}{0.33} \\
\hline & R: ACGTAGGAGTAGTTTCTAGGATT & & & & \\
\hline \multirow[t]{2}{*}{ SbAGE03 } & F: AGCTCTCAGCCTTTCACAAT & \multirow[t]{2}{*}{4} & \multirow[t]{2}{*}{2.00} & \multirow[t]{2}{*}{1.60} & \multirow[t]{2}{*}{0.37} \\
\hline & R: GGA AGA AAG GAA TGA CTT GA & & & & \\
\hline \multirow[t]{2}{*}{ SbAGF06 } & F: GTT AAA CGA CCA ATC ACC C & \multirow[t]{2}{*}{8} & \multirow[t]{2}{*}{1.88} & \multirow[t]{2}{*}{1.43} & \multirow[t]{2}{*}{0.27} \\
\hline & R: TAG AGG TGT CAC TGA TGA GC & & & & \\
\hline SbAGF08 & F: ATG GTC GTC TGT CCA GGT & 3 & 1.33 & 1.07 & 0.06 \\
\hline & R: CAG TTG CTA ATC TTT GAC CG & & & & \\
\hline $\mathrm{SbAGH04}$ & F: GGC ACT CAT GGA GTA ACA & 4 & 1.50 & 1.11 & 0.09 \\
\hline & R: TTT ATC CAA ATC AAA CCG G & & & & \\
\hline SvPEPCAA & F: GCA GCT CAG GGA CAA ATA C & 4 & 2.00 & 1.53 & 0.34 \\
\hline & R: CTG CTT CAG GTA AGG ATC G & & & & \\
\hline Total & & 38 & 1.68 & 1.38 & 0.23 \\
\hline
\end{tabular}

*Kimura and Crow (1964), ${ }^{* * N e i ’ s}(1973)$ gene diversity.

We performed a cluster analysis and generated a dendrogram using the UPGMA algorithm for genetic relationships (Figure 3) as described by Nei (1973). The sorghum cultivars were divided into three major groups based on clustering analysis of the SRR markers, with the exception of the DINE-A-MITE cultivar. Group 1 consisted of two introduced cultivars, one native Korean cultivar, and one breeding cultivar. Group 2 consisted of three native Korean cultivars. Group 3 consisted of one breeding cultivar and one native Korean cultivar.

The UPGMA-based dendrogram obtained using the Pearson's correlation matrix generated from the chemical analyses also showed variation in chemical composition (Figure 4). The dendrogram shows that the cultivars can be divided into three major clusters. 
Comparison of clusters based on chemical composition with those based on SSR data showed that the groups formed by the three native Korean cultivars clustered similarly in molecular dendrograms.

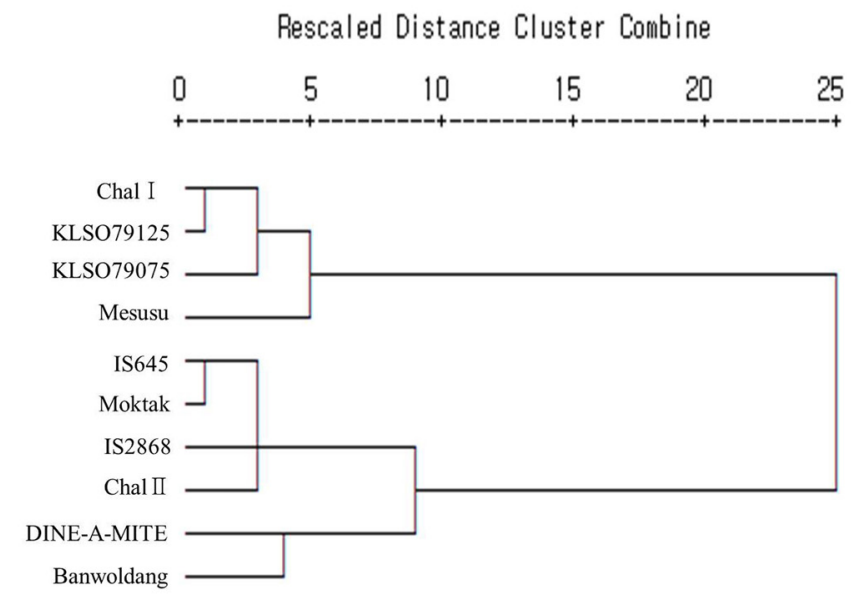

Figure 3. Unweighted pair-group method (UPGMA) dendrogram of selected sorghum based on Nei's (1973) genetic distance.

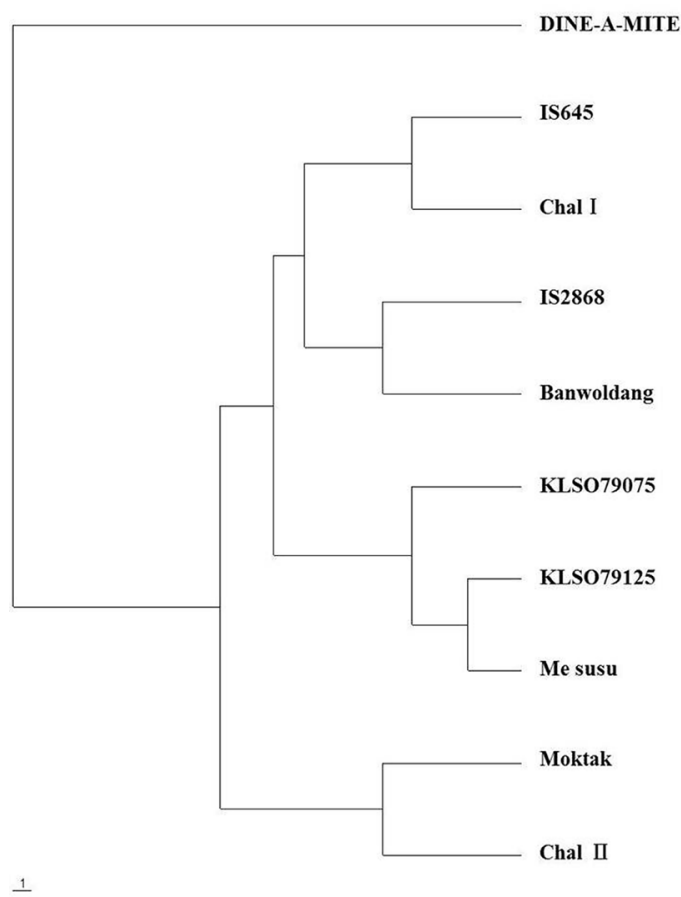

Figure 4. UPGMA dendrogram representing the similarity among selected sorghum for the chemical composition based on Pearson's correlation matrix.

Genetics and Molecular Research 15 (3): gmr.15038677 


\section{Marker-trait associations}

We explored marker-trait associations between SSR markers and the chemical components with the origin, seed color, growth characteristics, and $41 \mathrm{WP}$ and seed chemical components in the sorghum cultivars by applying Q GLM and Q + K MLM statistical methods (Table 10). We discovered four significant marker-trait associations for the concentration of seed color and the composition of WP fatty acids (linoleic acid and stearic acid).

Table 10. Association analyses between SSR markers and growth characteristics, origin, and chemical composition using different parts of the Sorghum germplasm.

\begin{tabular}{l|l|c|c|c|c}
\hline Trait & Marker & Q GML P value & $\mathrm{R}^{2}$ & Q+K MLM P value & $\mathrm{R}^{2}$ \\
\hline Seed color & SbAGB03 & 0.010 & 0.580 & 0.040 & 0.621 \\
\hline Seed color & SbAGE03 & 0.010 & 0.580 & 0.040 & 0.621 \\
\hline Whole plant linoleic acid & SbAGE03 & 0.002 & 0.722 & 0.044 & 0.630 \\
\hline Whole plant steric acid & SbAGB03 & 0.008 & 0.610 & 0.047 & 0.610 \\
\hline
\end{tabular}

$\mathrm{Q}$ GLM $=$ general linear model using the $\mathrm{Q}$ population structure matrix, $\mathrm{Q}+\mathrm{K}$ MLM $=$ mixed linear model using the Q population structure matrix and the K kinship matrix.

\section{DISCUSSION}

Ten cultivars were selected to investigate dry yield, seed yield, and sugar contents. The seed yields of the selected cultivars were similar to those reported by Rutto et al. (2013), who found that the seeds of sweet sorghum cultivars yielded $67-1240 \mathrm{~kg} / \mathrm{ha}$ when grown in Virginia. The sugar content of the sweet sorghum cultivar was similar to that of the DINEA-MITE cultivar in the present study. Widespread interest in the use of sorghum for ethanol production is attributed to its high content of extractable sugars, which are readily fermentable (Bennett and Anex, 2009; Rutto et al., 2013).

Sorghum is an important forage crop in semi-arid regions of the world. The DM yield of all cultivars studied in the present study ranged from 5.0 to 8.7 ton/ha. These results are similar to the DM yields observed by Cho et al. (2004), who reported that approximately 5 tons/ha DM of native sorghum cultivars could be harvested in Korea. NDF and ADF are two other important quality components of forage, which show opposite trends for digestibility. The NDF and ADF contents of the sorghum cultivars reported in the present study were within the ranges reported previously for corn (Mohammad et al., 2014). Protein yield is a combination of the total forage dry yield and forage $\mathrm{CP}$ content; therefore, growers are often more interested in higher protein yield per unit area than in values for specific protein content (Mohammad et al., 2014). Here, the highest protein yield was observed for the Banwoldang cultivar followed by KLSO79075 and Mesusu. The low protein yield of the Moktak cultivar was related to its low forage dry yield rather than its $\mathrm{CP}$ content. Minerals are important for good nutrition and can act to improve nitrogen utilization (Blackwood, 2007). The mineral contents of whole plants observed in the present study were similar to those reported by Blackwood (2007).

The importance of low levels of some unsaturated fatty acids in the growth and health of animals has been long known (Rooney and Waniska, 2000; Mehmood et al., 2008). The fatty acid composition observed in whole plants was similar to that reported by Burnett and Lohmar (1959). Staples et al. (1998) reported an increased interest in designing fat sources rich in $\omega-6$ (linoleic acid) and $\omega-3$ (linolenic acid) polyunsaturated fatty acids for delivery to the lower gut and subsequent absorption. 
It is likely that the Banwoldang cultivar is the most desirable because of its high protein content and dry yield, which indicate that this cultivar may be useful as a source of livestock feed.

Sorghum grains contain many different nutritive components. Amylose content is important for industrial food processing. It reportedly varies with genotype and is affected by climatic and soil conditions during grain development. The amylose content of seeds can be increased through breeding, as large variation is observed in grain sorghum (Gerrano et al., 2014). The amylose content of all the cultivars in the present study ranged from 10.70 to $21.35 \%$. These results are consistent with those of Gerrano et al. (2014) who reported amylose levels of $13-20 \%$. Quality assessment and breeding for higher concentrations of mineral contents in sorghum is important for improving human health (Blackwood, 2007). However, the mineral contents did not differ significantly among the cultivars.

An important feature of cereal crops is their diverse pool of fatty acids. The crude fat contents of the sorghum grain analyzed in this study were higher than those observed for wheat and rice (Rooney and Waniska, 2000). The highest oleic acid levels were observed in the DINE-A-MITE cultivar (Figure S3A), which were significantly lower than the oleic acid levels observed by Mehmood et al. (2008) who reported sorghum seed oil fatty acid compositions of $27.59-50.73 \%$ linoleic acid, $31.12-48.99 \%$ oleic acid, $0.43-0.56 \%$ palmitoleic acid, $1.71-3.89 \%$ linolenic acid, and 1.09-2.59\% stearic acid. Low oleic acid levels were due to the segregated plant analysis (whole grain and grain). Typically, the linoleic acid content is higher in the whole grain than in the bran. Our findings suggest that the whole grain may serve as a dietary source of monounsaturated fatty acids and polyunsaturated fatty acids (Mehmood et al., 2008).

Sorghum contains high levels of functional compounds within the grain, including tannins, flavonoids, and anthocyanins. Tannins are unique phytochemical components of sorghum, which have significant effects on animals and have also been reported to have both positive and negative impacts on human health (Awika and Rooney, 2004). Plant breeders are continuously improving sorghum cultivars. Reduced tannin levels in sorghum have greatly improved nutrient digestibility for poultry. The tannin contents of the sorghum cultivars analyzed in this study were generally low compared with the values reported by Jambunathan and Mertz (1973), who considered a level of more than $10 \mathrm{mg} / \mathrm{g}$ of grain to be high. Kim et al. (2010) reported similar values of total flavonoid content for five other sorghum cultivars.

Anthocyanins have been demonstrated to play a very important role in plant physiology and are important for human health. Luteolinidin and apigeninidin were the most abundant 3-deoxyanthocyanins in sorghum grain in the present study (Awika et al., 2004; Awika and Rooney, 2004). Luteolinidin is toxic to fungi and accumulates at increased levels in sorghum lines resistant to the anthracnose fungus (Lo et al., 1999). The highest level of apigeninidin was observed in the Banwoldang cultivar $(4.19 \mathrm{mg} / 100 \mathrm{~g})$ and the lowest levels was observed in the IS 2868 cultivar $(0.57 \mathrm{mg} / 100 \mathrm{~g})$. The levels of glycosides of apigeninidin ranged from 0.06 to $1.05 \mathrm{mg} / 100 \mathrm{~g}$, with an average of $0.26 \mathrm{mg} / 100 \mathrm{~g}$ among the cultivars. The high levels of these compounds observed in the present study, especially for the KLSO79075 cultivar, indicate promising commercial potential for sorghum as a source of 3-deoxyanthocyanins. This group of anthocyanins is uncommon and is specifically distributed in certain plants; sorghum is considered to be the only dietary plant source of these chemicals (Clifford, 2000). Awika et al. (2004) reported that the anthocyanin content ranges from 2.8 to $4.3 \mathrm{mg} / \mathrm{g}$ in red sorghum, and that black sorghum has the highest anthocyanin content (an average of $10.1 \mathrm{mg} / \mathrm{g}$ in bran).

Genetics and Molecular Research 15 (3): gmr.15038677 
Both condensed tannins and 3-deoxyanthocyanidins have potential health benefits, and have antioxidant and anti-carcinogenic properties (Awika and Rooney, 2004).

In this study, high levels of genetic diversity were found for the various cultivars studied. Motlhaodi et al. (2014) found similar levels of diversity among 30 sorghum cultivars. Ng'uni et al. (2011) observed high diversity among 27 Zambian sorghum accessions using 10 SSR primer sets. Based on the origin, the dendrogram revealed an unclear pattern of division among the cultivars. Given that the cultivars evaluated in this study were breeding cultivars of mixed pedigrees, it is likely that cluster analysis using country of origin and race information was not able to differentiate among all cultivars because of the limited number of accessions (Agrama and Tuinstra, 2003). Of the four samples clustered together in Group 1, three were also clustered similarly in molecular dendrograms. Low correlations between genetic and chemical groupings have also been reported in various studies (Agrama and Tuinstra, 2003; Iqbal et al., 2010; Pandotraet al., 2013). To our knowledge, this is the first report on the association of molecular markers with fatty acid profiles in sorghum. These markers could be used for the selection of sorghum cultivars with improved fatty acid composition. The degree of association between SSR markers and fatty acid content should be confirmed in further independent studies with more extensive molecular analyses.

In conclusion, analysis of chemical composition may be helpful for the selection of sorghum cultivars for cultivation. This study also provides two molecular markers that can be used to identify fatty acid profiles of sorghum cultivars. Therefore, these results may contribute to the selection of parental lines for both traditional and mutational breeding of sorghum.

\section{Conflicts of interest}

The authors declare no conflict of interest.

\section{ACKNOWLEDGMENTS}

Research supported by a grant from the Korea Atomic Energy Research Institute (KAERI), Republic of Korea.

\section{REFERENCES}

Agrama HA and Tuinstra MR (2003). Phylogenetic diversity and relationships among sorghum accessions using SSRs and RAPDs. African J. Biotech. 2: 334-340. http://dx.doi.org/10.5897/AJB2003.000-1069

Awika JM and Rooney LW (2004). Sorghum phytochemicals and their potential impact on human health. Phytochemistry 65: 1199-1221. http://dx.doi.org/10.1016/j.phytochem.2004.04.001

Awika JM, Rooney LW and Waniska RD (2004). Properties of 3-deoxyanthocyanins from Sorghum. J. Agric. Food Chem. 52: 4388-4394. http://dx.doi.org/10.1021/jf049653f

AOAC (1990). Official Methods of Analyses, 15th edn. Washington, DC, USA: Association of Official Analytical Chemists.

AOAC (1995). Official Methods of Analyses, 16th edn. Washington, DC, USA: Association of Official Analytical Chemists.

Bennett AS and Anex RP (2009). Production, transportation and milling costs of sweet sorghum as a feedstock for centralized bioethanol production in the upper Mid-west. Biores. Technol. 100: 1595-1607. http://dx.doi. org/10.1016/j.biortech.2008.09.023

Blackwood L (2007). Mineral content of common ruminant stockfeeds, crops and pastures. NSW Department of Primary Industries. 522: 1-7.

Genetics and Molecular Research 15 (3): gmr.15038677 
Bradbury PJ, Zhang Z, Kroon DE, Casstevens TM, et al. (2007). TASSEL: software for association mapping of complex traits in diverse samples. Bioinformatics 23: 2633-2635. http://dx.doi.org/10.1093/bioinformatics/btm308

Burnett MC and Lohmar RL (1959). Fatty acids of sorghum leaf and stem. Agric. Food Chem. 7: 436-437. http://dx.doi. org/10.1021/jf60100a012

Cho NK, Kang YK, Song CK, Jeun YC, et al. (2004). Effects of seeding date on ecological response, forage yield potential and chemical composition in jeju native sorghum (Sorghum bicolor L.). Korean J. Grassl. Sci. 24: 231-236. http:// dx.doi.org/10.5333/KGFS.2004.24.3.231

Clifford MN (2000). Anthocyanins-nature, occurrence and dietary burden. J. Sci. Food Agric. 80: 1063-1072. http:// dx.doi.org/10.1002/(SICI) 1097-0010(20000515)80:7<1063::AID-JSFA605>3.0.CO;2-Q

Dykes L, Seitz L, Rooney WL and Rooney LW (2009). Flavonoid composition of red sorghum genotypes. Food Chem. 116: 313-317. http://dx.doi.org/10.1016/j.foodchem.2009.02.052

Fang G, Hammer S and Grumet R (1992). A quick inexpensive method of removing ploysaccharides from plant genomic DNA. Biotechniques 13: 52-55.

FAO (2004). Production Year Book 2002 No. 56. FAO Stat. Ser 176 - Food and Agriculture Organization of the United Nations, Rome, Italy.

Gebhardt C, Ballvora A, Walkemeier B, Oberhagemann P, et al. (2004). Assessing genetic potential in germplasm collections of crop plants by marker-trait association: a case study for potatoes with quantitative variation of resistance to late blight and maturity type. Mol. Breed. 13: 93-102. http://dx.doi.org/10.1023/B:MOLB.0000012878.89855.df

Gerrano AS, Labuschagne MT, van Biljon A and Geleta N (2014). Genetic variability among sorghum accessions for seed starch and stalk total sugar content. Sci. Agric. 71: 472-479. http://dx.doi.org/10.1590/0103-9016-2013-0322

Hardy OJ and Vekemans X (2002). SPAGeDi: a versatile computer program to analyses spatial genetic structure at the individual or population levels. Mol. Ecol. Notes 2: 618-620. http://dx.doi.org/10.1046/j.1471-8286.2002.00305.x

Iqbal A, Sadia B, Khan AI, Awan FS, et al. (2010). Biodiversity in the sorghum (Sorghum bicolor L. Moench) germplasm of Pakistan. Genet. Mol. Res. 9: 756-764. http://dx.doi.org/10.4238/vol9-2gmr741

Jambunathan R and Mertz ET (1973). Relationship between tannin levels, rat growth and distribution of protein in sorghum. Agric. Food Chem. 21: 599-692. http://dx.doi.org/10.1021/jf60188a027

Kim JS, Hyun TK and Kim MJ (2010). Anti-oxidative activities of sorghum, foxtail millet and proso millet extracts. Afr. J. Biotechnol. 9: 2683-2690.

Kimura M and Crow JF (1964). The number of alleles that can be maintained in a finite population. Genetics 49: 725-738.

Lo SCC, De Verdier K and Nicholson RL (1999). Accumulation of 3-deoxyanthocyanidin phytoalexins and resistance to Colletotrichum sublineolum in sorghum. Physiol. Mol. Plant 55: 263-273. http://dx.doi.org/10.1006/pmpp.1999.0231

Lu X, Zhou H, Pan YB, Chen CY, et al. (2015). Segregation analysis of microsatellite (SSR) markers in sugarcane polyploids. Genet. Mol. Res. 14: 18384-18395. http://dx.doi.org/10.4238/2015.December.23.26

Makkar HPS (2000). Qualification of tannins in tree foliage. A laboratory manual for the FAO/IAEA Co-ordinated research project on use of nuclear and related techiques to develop simple tannin assays for predicting and improving the safety and efficiency of feeding ruminants on tanniniferous tree foliage. Joint FAO/IAEA, FAO/IAEA of Nuclear Techniques in Food and Agriculture. Animal Production and Health Sub-program, FAO/IAEA Working Document. IAEA, Vienna, Austria.

Mohammad RZ, Reza KF, Hassan H and Masoud H (2014). Evaluation of yield and quality of sorghum and millet as alternative forage crops to corn under normal and deficit irrigation regimes. Agric. Sci. 10: 699-715.

Motlhaodi T, Gleleta M, Bryngelsson T, Fatih M, et al. (2014). Genetic diversity in ex-situ conserved sorghum accessions of Botswana as estimated by microsatellite markers. Australian J. Crop Sci. 8: 35-43.

Ng'uni D, Geleta M and Bryngelsson T (2011). Genetic diversity in sorghum (Sorghum bicolor (L.) Moench) accessions of Zambia as revealed by simple sequence repeats (SSR). Hereditas 148: 52-62. http://dx.doi.org/10.1111/j.16015223.2011.02208.x

Nei M (1973). Analysis of gene diversity in subdivided populations. Proc. Natl. Acad. Sci. U.S.A. 70: 3321-3323. http:// dx.doi.org/10.1073/pnas.70.12.3321

Pandotra P, Gupta AP, Husain MK and Gupta GS (2013). Evaluation of genetic diversity and chemical profile of ginger cultivars in north-western Himalayas. Biochem. Syst. Ecol. 48: 281-287. http://dx.doi.org/10.1016/j.bse.2013.01.004

Rooney LW and Waniska RD (2000). Sorghum food and industrial utilization. In Sorghum, origin, history, technology and production (Smith CW and Frederiksen RW, eds.). Wiley press, New York, 689-729.

Rutto LK, Xu Y, Brandt M, Ren S, et al. (2013). Juice, Ethanol, and grain yield potential of five sweet sorghum (Sorghum bicolor [L.] Moench) cultivars. J. Sustainable Bioenergy Sys. 3: 113-118. http://dx.doi.org/10.4236/jsbs.2013.32016

Mehmood S, Orhan I, Ahsan Z, Aslan S, et al. (2008). Fatty acid composition of seed oil of different Sorghum bicolor cultivars. Food Chem. 109: 855-859. http://dx.doi.org/10.1016/j.foodchem.2008.01.014

Genetics and Molecular Research 15 (3): gmr.15038677 
Sedghi M, Ebadi MR, Golian A and Ahmadi H (2011). Estimation and modeling true metabolizable energy of sorghum grain for poultry. Poultry Sci. 90: 1138-1143. http://dx.doi.org/10.3382/ps.2010-01005

Staples CR, Burke JM and Thatcher WW (1998). Influence of supplemental fats on reproductive tissues and performance of lactating cows. Dairy Sci. 81: 856-871. http://dx.doi.org/10.3168/jds.S0022-0302(98)75644-9

Wortmann CS, Liska AJ, Ferguson RB, Lyon DJ, et al. (2010). Dryland Performance of Sweet Sorghum and Grain Crops for Biofuel in Nebraska. Agronomy 102: 319-326. http://dx.doi.org/10.2134/agronj2009.0271

Zhishen J, Mengcheng T and Jianming W (1999). The determination of flavonoid contents in mulberry and their scavenging effects on superoxide radicals. Food Chem. 64: 555-559. http://dx.doi.org/10.1016/S0308-8146(98)00102-2

\section{Supplementary material}

Figure S1. Spectral characteristics of 3-deoxyanthocyanidins isolated from sorghum by UPLC. A. luteolinidin (LGC) B. apigeninidin (sigma) C. glycosides of apigeninidin (Awika et al., 2004).

Figure S2. Spectra of GC-MS for fatty acid analysis of whole sorghum plants. Peak $1=$ palmitic acid, Peak 2 $=$ palmitoleic acid, Peak $3=$ stearic acid, Peak $4=$ oleic acid, Peak $5=$ linoleic acid, Peak $6=\alpha$-linolenic acid. A. DINE-A-MITE, B. IS645, C. IS2868, D. Moktak, E. Banwoldang, F. ChalI, G. ChalII, H. KLSO79125, I. KLSO79075, J. Mesusu.

Figure S3. Spectra of GC-MS for fatty acid analysis of sorghum whole grain. Peak $1=$ palmitic acid, Peak $2=$ stearic acid, Peak 3 = oleic acid, Peak 4 = linoleic acid, Peak $5=\alpha$-linolenic acid, A. DINE-A-MITE, B. IS645, C. IS2868, D. Moktak, E. Banwoldang, F. ChalI, G. ChalII, H. KLSO79125, I. KLSO79075, J. Mesusu.

Figure S4. HPLC profiles of black and red sorghum 3-deoxyanthocyanins detected at $480 \mathrm{~nm}$. Peaks 1 and 2 are luteolinidin and apigeninidin, respectively. Peak 3 was tentatively identified as glycosides of apigeninidin. Peaks were identified on the basis of matching retention times and spectral characteristics with commercial standards. A. DINE-A-MITE, B. IS645, C. IS2868, D. Moktak, E. Banwoldang, F. ChalI, G. ChalII, H. KLSO79125, I. KLSO79075, J. Mesusu.

Table S1. Origin and seed yield of Sorghum germplasm for cultivar selection.

Table S2. Identification of 3-deoxyanthocyanin levels in Sorghum whole grain.

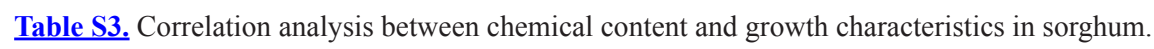

